\title{
The Impact Of Employee Stock Bonus On Equity Market Value
}

\author{
Niensu Shih, Feng Chia University, Taiwan
}

\begin{abstract}
This paper explores the relation between equity market value and the expense of employee stock bonus that is disclosed but not recognized under Taiwan's law. Employing the regression analyses, and to investigate the effects of employee stock bonus on the firm's share price. We find that the market value of employee stock bonus has a negative effect on the firm's share price. The result indicates the negative side of employee stock bonus is its dilution of the existing shareholders' equity rights.
\end{abstract}

Keywords: Residual income valuation, Employee stock bonus, equity value

\section{INTRODUCTION}

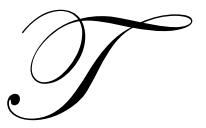

he objective of this study is to understand the relation between equity market values and the expense of employee stock bonus that is disclose, but not recognized in net income. According to Taiwan's Law of Corporation of 1980, employee stock bonus in Taiwan is treated as an after-tax distribution of net income, instead of pretax compensation expense. that is ,but not recognized in net income. Under this employee stock bonus plan, employees can get a large amount of rewards in reality with low taxes since employees will be taxed on the par value of the stock bonus that is far below the market value. In late nineties, electronic firms generally distribute stock bonus to their employees. People in Taiwan, therefore, dreamed of joining the high-tech industry. The employee stock bonus plan not only attracts talents to work for industries, but it has also created a high-tech legend of Hsinchu Science Park in Taiwan (Chen and Wang 2001). ${ }^{1,2}$ Nalbantian and Schotter (1997) pointed out that sharing the company's after-tax earnings with employees may be the most effective way to increase a firm's productivity, both in the short run and in the long run.

Distributing employee stock bonus to employees makes employees become the owner of a firm they work for. The bonus plan can encourage employees to stay and serve in the firm, hoping to enhance the operation and to raise productivity. Under the employee stock bonus plan, employees not only share the business earnings, but also undertake the risk of business. The current accounting in Taiwan treats employee stock bonus as a distribution of after-tax earnings at par value of NT\$10 per share instead of a tax-deductible expense. Such accounting treatment is contradictory to the international accounting practice that treats the fair value of employee stock plan as a compensation expense. Since the remuneration expenses of employee stock bonus are not included in the costs of production in Taiwan, the U. S. enterprises often accuse their competitors from Taiwan of dumping low-priced products to the U. S. In order to fix this problem and to make Taiwan's accounting treatments synchronizing with international standards, Taiwan's Law of Business Accounting was amended on May 24, 2006 to revise the clause on employee bonus and required employee bonuses should be treated as expenses. Considering the possible serious impact, Taiwan's Ministry of Economic Affairs mandates that employee bonuses shall be treated as compensation expenses from January 1, 2008 on.

\footnotetext{
${ }^{1}$ Hsinchu Science Park has already become a place that produces star firms in Taiwan. Total sales volume for firms in this science park represented 1.28\% of Taiwan's GDP in 1994, and quickly rose to $7.05 \%$ in 2002.

2 A survey conducted by Chen and Wang (2002) showed that the world market shares of electronics products made in Taiwan are: Mice (60\%), Main Boards (61\%), Keyboards (65\%), Scanners (84\%), Monitors (58\%), Network Interface Cards (39\%), Power Supplies (66\%), VGA Cards (31\%), Notebooks (40\%) and CD-ROMs (34\%).
} 
Although many studies point out that an employee stock bonus plan can bring economic benefits for the business, it also deteriorates shareholders' equity to a certain extent. The value of employee stock represents a cost of generating earnings. We test the relation between share price and the expense of employee stock bonus, incremental to net income, equity book value, and expected earnings growth, we predict a negative relation between the expense and share price. To obtain data for our tests, we collect the firm with employee stock bonus from firms listed in the Taiwan Stock Exchange from the period 1997-2005. Financial and market data are from the Taiwan Economic Journal databanks. We find a significant negative relation between share price and the expense of employee stock bonus that is disclosed, but not recognized in net income, after controlling for net income, equity book value, and expected earnings growth.

The remainder of the paper proceeds as follows. In the following section, we will develop our hypotheses based on existing research in employee stock bonus. Section three explains our research methodology. Empirical results are illustrated in Section four. Section five expounds our conclusions.

\section{II . BACKGROUND AND HYPOTHESES DEVELOPMENT}

According to the generalized stock valuation model, the price of a firm is determined by discounting its future earnings using appropriate discount rates. Thus, accounting earnings are one of the most basic and important determinants of stock price. The theoretical "residual income valuation model" proposed by Ohlson (1995) and Feltham and Ohlson (1995) argued that a firm's market value can be expressed as the book value plus the present value of future abnormal earnings. This theoretical development has important implications for empirical researchers, as Ohlson's model specifies the relationship between stock price and accounting variables such as earnings and the book value of a firm.

In the past two decades, more and more U. S. enterprises used stock-based compensation (e.g. employee stock option plans) to motivate their employees. Under APB Opinion No. 25, a firm is required to record a compensation expense that is equal to the difference between the market value of the shares on the date the option was granted to employees and the exercise price of that stock option. However, companies can easily avoid recognizing the expense of stock-based compensation by granting options that exercise price is set as the stock price on the grant date. In fact, Taiwan's "employee stock bonus plans" is very similar to the stock option in the U. S. However, the accounting treatments between the U. S. and Taiwan are different. According to Taiwan's Law of Corporation, the employee stock bonus plan is regarded as a distribution of after-tax income and therefore incurs no recognition as a compensation expense. In October of 1995, the FASB made a concession and issued Statement No. 123. SFAS No. 123 encourages firms to recognize compensation expenses in the income statement for stock-based compensation based on the estimated fair value on the grant (the "fair value method"). As an alternative, a firm can choose to use the intrinsic value method under APB Opinion No. 25 and disclose pro-forma net income and EPS as if they had used the fair value method. Coller and Higgs (1997) found that the choices of stock option valuation models and model variable measurements could result in material differences in compensation expenses even under the acceptable procedures of FASB. As a result, it is difficult to compare the information of firms' employee stock options among firms. Espahbodi et al. (2002) documented that firms exhibited significant abnormal returns around the issuance of the Exposure Drafts proposing to require recognition of compensation costs in fair value, especially for high-tech, high-growth, and start-up firms. Examining firms in the electronic industry in Taiwan from 1995 to 1998, Chang (1999) showed that stock prices reflected the reported earnings without including the expense of employee stock bonus. She conjectured that the privacy and dilution effect of employee stock bonus fail to be understood by investors immediately on the announcement date of employee stock bonus. Another explanation was that investors might view employee stock bonus as a work incentive for employees and thus compensate for its expenses.

From an accounting point of view, when services or products are rendered and revenue is recognized, all related expenses shall be recognized in the same period (the "matching principle"). Therefore, compensation costs of employee stock bonus must match the revenue recognized in the period when employees are granted to receive the bonus. Compensation costs of employee stock bonus should be tied to the improvement in employees' performance. 
From the empirical model of Ohlson (1995), we know that:

$$
V_{\text {equity }}(E)_{t}=\pi_{0} B V_{t}+\pi_{1} R I_{t+1}+\cdots+\pi_{k} R I_{t+k} \text {. . . . . . . }
$$

$B V_{t}$ : book value of equity;

$R I_{t+k}:$ forecasts of future residual income.

If a firm distributes employee stock bonus, both stockholders and employees have right to claim on future earnings. Therefore, both the book value of equity and future residual incomes must be adjusted to reflect the employee compensation costs in order to better estimate the fair value of equity in Equation (1), this leads to hypothesis one:

$\boldsymbol{H}_{1}$ : A firm's equity market value is negatively related with the fair value of employee stock bonus it distributes.

\section{RESEARCH METHODOLOGY}

\section{A. Sample And Data}

Sample data was drawn from firms listed on the Taiwan Stock Exchange and complied in the Taiwan Economic Journal (TEJ) Database from 1997-2005. The initial sample consisted of 6,045 firm-year observations. We remove firms with missing value in financial statements or stock price. We eliminate such firms in the banking and insurance industries. Taken together, our final sample consists of 772 observations with employee stock bonus and 3,073 observations without employee stock bonus.

Table 1 presents the industry distribution for firms used in our analyses. The statistics indicate that the electronics industry has the most firms, totaling 222 companies, adopting employee stock bonus plans compared with other industries. This represents $72.08 \%$ of the all sample firms with employee stock bonus plans. The next one is the electrical engineering industry having 17 firms (5.52\%), and then the chemical industry with 15 firms (4.87\%). Companies in the other industries than electronics have fewer firms adopting employee stock bonus plans. Their total aggregation was only 54 companies, representing 17.53\% (54/308) of our sample firms.

\section{Table 1}

Industry distribution of sample firms

\begin{tabular}{lrr}
\hline Industry Description $^{\mathbf{a}^{2}}$ & Number & \% \\
\hline Food & 3 & 0.97 \\
Plastics & 3 & 0.97 \\
Textiles & 5 & 1.63 \\
Engineering \& Machinery & 17 & 5.52 \\
Appliance \& Cable & 3 & 0.97 \\
Chemicals & 15 & 4.87 \\
Steel \& Iron & 3 & 0.97 \\
Electronics & 222 & 72.08 \\
Construction & 9 & 2.93 \\
Other & $\underline{28}$ & $\underline{909}$ \\
Total & $\underline{\underline{308}}$ & $\underline{100.00}$ \\
\hline
\end{tabular}

${ }^{a}$ Industry categories are determined by Taiwan Stock Exchange Industry Code as follows: food (12), plastics (13), textiles (14), engineering \& Machinery (15), appliance \& cable (16), chemicals (17), steel \& iron (20), electronics (23,24,30-34,52-54,61-62), construction (25), and other (11,18,19,21,26,29, and 99). 


\section{B. Model Specification}

This study purposes to examine the relationship between a firm's equity market value and employee stock bonus it granted. Since a firm determining to distribute employee stock bonuses definitely has its own reasons, it may be these determinants affecting the firm's market value rather than the fair value of employee stock plan itself. If so, then the coefficient of our regression may be biased. In order to avoid this "self-selection bias", the two-stage estimation of Heckman (1976) is used in our study. In the first stage, the determinants of employee stock bonus equation are estimated using the probit analysis. In the second stage, the inverse Mill's ratio obtained from the first stage is included in the second stage regression models to test the hypotheses of this study. perspectives:

Determinants of adopting an employee stock bonus plan can be explained in the following two

\section{(1) Incentive consideration}

Guay (1999), and Core and Guay (1999) documented that "firm size" and "growth opportunities" are major determinants for a firm to grant stock options to its employees for incentive purposes. Prior studies provide many variables, such as sales, total assets, and the number of employees, as proxies for the "firm size". Since employee stock bonus plan is an incentive device for employees, the number of employees will affect the degree of incentive. Thus, the "firm size" is measured by the number of employees $(N O)$ and the natural log of total assets $(L A)$ in our study. Smith and Watts (1992) found that firms with higher growth rates make greater use of stock-based compensation plans. Kole (1991) and MacKie-Mason (1990) pointed out that a firm having higher R \& D expenditures generally has more investment in innovative products for forming a higher barrier to entry. To measure a firm's "growth opportunities", we use the rate of sales growth $(S G)$ and the ratio of R \& D expenditures to sales $(D T R)$. In addition, the financial performance of a firm will affect a firm's willingness to distribute stock bonuses to its employees for incentive purpose. The financial performance is measured by return on assets (ROA), which is defined as net income before interest and taxes divided by total assets.

\section{Other considerations}

Prior studies documented that firms in the new economy usually adopt equity-based compensation plans (Espahbodi et al. 2002, Ittner et al. 2003, among others). Our sample also shows that $72.08 \%$ of firms in the electronics industry adopt employee stock bonus plans. Therefore, a dummy variable $(H T)$ is included in our probit model for employee stock bonus to capture the effect of industry, where $H T$ is an indicator variable with a value of 1 if the firm is in the electronics industry, and 0 otherwise.

The probit model using to estimate the determinants of the employee stock bonus equation is:

$\begin{aligned} Y_{i t}= & \beta_{0}+\beta_{1} N O_{i t}+\beta_{2} L A_{i t}+\beta_{3} S G_{i t}+\beta_{4} D T R_{i t}+\beta_{5} R O A_{i t} \\ & +\beta_{6} H T_{i t}+e_{i t} \ldots \ldots . . . . . . .\end{aligned}$

$Y^{*}=1$, if $Y_{i t}>0$, the firm has an employee stock bonus plan, and

$Y^{*}=0$, if $Y_{i t} \leq 0$, the firm does not have an employee stock bonus plan.

$N O_{i t}$ : the number of employees for firm $i$ during period $t$;

$L A_{i t}$ : the natural $\log$ of total assets for firm $i$ during period $t$;

$S G_{i t}$ : the sales growth rate for firm $i$ during period $t$;

$D T R_{i t}$ : the ratio of $\mathrm{R} \& \mathrm{D}$ expenditures to sales for firm $i$ during period $t$;

$R O A_{i t}:$ net income before interest and taxes divide by total assets for firm $i$ during period $t$;

$H T_{i t}$ : Dummy $=1$ if the firm is in the electronics industry, and 0 otherwise.

The second stage of the Heckman's two-stage method solves the "self-selection bias" problem by including the inverse Mills ratio generated from the probit model of Equation (2) into the following regression models. In 
Heckman's two-stage method, we focus on the following equation model to test our H1 (The firm's equity market value is negatively related to the fair value of employee stock bonus) as follows:

$$
P_{i t}=\alpha_{0}+\alpha_{1} B V_{i t}+\alpha_{2} N I_{i t}+\alpha_{3} S B O_{i t}+\alpha_{4} G W_{i t}+\varepsilon_{i t} \cdots \ldots \cdot(3)
$$

$P$ is share price, $B V$ is equity book value, $N I$ is net income, $S B O$ is the fair value of employee stock bonus, and $G W$ is earnings growth opportunity. The primary objective of this study is to explore whether the equity market value of a firm is affected by the fair value of employee stock bonus. Based on the economic substance, the employee stock bonus shall be accounted for at their fair value and be expensed. Generally, the actual amount of employee sock bonus is unknown at year end. However, an investor knowing the current year's earnings would be able to estimate the number of shares of employee stock bonus for the current year by referring to the earnings and the number of shares of employee stock bonus distributed in the prior year. The ex-post actual number of employee stock bonus distributed is not used to calculate their value because the required deadlines for both annual and the first quarterly reports are same on April 30 in Taiwan, share price in such a way will mix the annual and the first-quarter earnings information and increase the noise in the department variable. Therefore, we use the expected value of employee stock bonus at year-end (the expected number of shares of employee stock bonus times the yearend stock price) as the independent variable. In addition, the distribution of employee stock bonus will inflate the contributed capital, and dilute the equity right of original shareholders. Therefore, we predict a negative effect between the share price and the fair value of employee stock bonus. The expected numbers of shares of employee stock bonus to be distributed for the current year is defined as the actual number of shares of employee stock bonus distributed for the prior year multiplied by the ratio of the current income to last year's income. The fair value of employee stock bonus per share $(S B O)$ to be distributed for the current year is calculated by multiplying the ending stock price with the ratio of the expected number of shares of employee stock bonus to the sum of the ending number of shares of common stock outstanding and that of employee stock bonus.

In the knowledge economy, the value of an enterprise depends on the quality of its human resources, the ability to innovate, and R\&D, especially in high-tech industries. ${ }^{3}$ The employee stock bonus system adopted by many firms in Taiwan is used to attract and retain valuable employees and eventually to create shareholder value. ${ }^{4}$ If the company can maintain its growth, the shareholders can make some sacrifice in their equities in exchange of greater reward. Adopting an employee stock bonus plan in this case will be a win-win situation. However, if the operation of the company is not good, the more shares distributed and the higher the fair value of employee stock bonus are, the more value investors' equities will lose. The market to book ratio of equity and Tobin's $Q$ have been used to measure the growth opportunities in literature. Fama and French (1993), and Collins and Kothari (1989), employed the ratio of market value of equity to its book value as the proxy for a firm's growth opportunities. If a firm has higher growth opportunities, it will have a higher expected equity return and thus a higher market to book ratio. In this study, the ratio of market to book value of equity is used as the proxy of growth opportunities. Yoon and Starks (1995) pointed out that the calculation of Tobin's Q faced difficulties in terms of its data requirements and computational effort. We do not use Tobin's $Q$ as the proxy of the growth opportunities in our study.

\section{RESULTS AND ANALYSIS}

\section{A. Descriptive Statistics}

Our sample is composed from firms listed in the Taiwan Stock Exchange from the period 1997-2005. Financial and market data are from the Taiwan Economic Journal databanks. Table 2 provides descriptive statistics for 772 firm-year observations. It reveals that the mean of fair value of employee stock bonus per share is 0.5698 , with a maximum value of $13.3765 .^{5}$ Therefore, companies are apt to ignore the cost employee stock bonus to a firm, and thus distribute employee stock bonus generously.

Ke (2002), Accounting Research Monthly 174: 14-15

$4 \mathrm{Ma}$ (1998) pointed out that the United Microelectronics Corp. distributed employee stock bonus over 15 years, resulting in an average of $0.43 \%$ dilution on contributed capitals per annum, and created about 14.5 times of ROE reduction per annum.

5 Wang (2002) pointed out that the average ratio of fair value of employee stock bonus to the total contributed capital was about $1.2 \%$ in 2002 in Taiwan. The average ratio of employee stock bonus to total capitalization of profits was about $15 \%$. 
Table 2

Descriptive Statistics for Variables ( $\mathrm{N}=772$ )

\begin{tabular}{|c|c|c|c|c|c|}
\hline Variable & Mean & Std. dev. & Min & Median & Max \\
\hline$P$ & 33.222 & 38.9756 & 11.8 & 21.26 & 770.4 \\
\hline$B V$ & 18.0099 & 5.5761 & 8.78 & 16.32 & 48.61 \\
\hline$N I$ & 2.3684 & 1.9949 & -1.05 & 1.76 & 10.6 \\
\hline$S B O$ & 0.5698 & 1.1275 & 0.0002 & 0.2093 & 13.3765 \\
\hline$G W$ & 2.2879 & 1.4867 & 0.2780 & 1.8974 & 11.0928 \\
\hline
\end{tabular}

Definition of variables:

$P:$ the share price;

$B V$ : the equity book value;

$N I$ : the firm's net income;

$S B O$ : the expected fair value of employee stock bonus per share;

$G W$ : earnings growth opportunities, defined as a firm's market to book value measured at the beginning year.

For the basic uni-variate analyses, we first computed the Pearson correlations for variables used in this study to assess whether employee stock bonus influences share price. Table 3 provides the correlation matrix of Pearson for all variables. As expected, Pearson correlations among the major variables are significantly different from zeros. The share price $(P)$ are significantly and positively correlated with book value $(B V)$ and net income $(N I)$ of the firm. Also, the correlation between share price and fair value of employee stock bonus per share ( $S B O)$ is negative as expected, but not significant. The growth opportunities $(G W)$ is insignificantly, and positively, correlated with share price. The coefficients on fair value of employee stock bonuses per share with net income and growth opportunities are significantly positive in Spearman correlations. This implies that the more growth opportunities and the higher the firms' risks are, the higher the fair value of employee stock bonuses will be, and vice versa.

Table 3

Pearson Correlations $(\mathrm{N}=772)$

\begin{tabular}{|c|c|c|c|c|c|}
\hline & $P$ & $B V$ & $N I$ & $S B O$ & $G W$ \\
\hline$P$ & 1 & & & & \\
\hline$B V$ & $\begin{array}{c}0.324^{* * *} \\
(0.000)\end{array}$ & 1 & & & \\
\hline$N I$ & $\begin{array}{l}0.336^{* * *} \\
(0.000)\end{array}$ & $\begin{array}{c}0.355^{* * *} \\
(0.000)\end{array}$ & 1 & & \\
\hline$S B O$ & $\begin{array}{l}-0.061 \\
(0.269)\end{array}$ & $\begin{array}{l}-0.075 \\
(0.170)\end{array}$ & $\begin{array}{c}0.202^{* * *} \\
(0.000)\end{array}$ & 1 & \\
\hline$G W$ & $\begin{array}{c}0.026 \\
(0.476)\end{array}$ & $\begin{array}{l}0.316^{* * *} \\
(0.000)\end{array}$ & $\begin{array}{l}0.516^{* * *} \\
(0.000)\end{array}$ & $\begin{array}{l}0.087^{* *} \\
(0.016)\end{array}$ & 1 \\
\hline
\end{tabular}

$* * *, * *, *$ indicate coefficient is significant at the $1 \%, 5 \%, 10 \%$ level, respectively.

See table 2 for definition of variables.

\section{B. Regression Analysis}

\section{$\underline{\text { Probit regression }}$}

This section presents our empirical results about the effect of the fair value of employee stock bonus on the equity market value of a firm. Table 4 reports results of the probit analysis. The coefficient of industry variable ( $H T$ ) is significantly positive, meaning the electronics industry prefers to adopt employee stock bonus plans. We find that 
the coefficient of the number of employees $(N O)$ is negative and statistically significant. This finding suggests that the number of employees of a firm with employee stock bonus is less than that for a firm without it. The fewer the number of employees a firms has, the higher the motivation effect of employee stock bonus will be. The coefficient of a firm's total assets $(L A)$ is significantly positive, possibly due to firms with employee stock bonus being in the capital-intensive electronics industry. Or alternatively, large firms tend to adopt employee stock bonus plans than small firms do. The coefficient of a firm's total assets ( $L A)$ is significantly positive, possibly due to firms with employee stock bonus being in the capital-intensive electronics industry. Or alternatively, large firms tend to adopt employee stock bonus plans than small firms do. We find a positive coefficient of R\&D expenditures $(D T R)$ and a negative coefficient for sales growth $(S G)$, both are insignificant. In addition, the coefficient for return on assets $(R O A)$ is significantly positively, suggesting that better performance encourages the adoption of an employee stock bonus plan.

Table 4

Probit Regression Results for the Determinant of Employee Stock Bonus Grants

\begin{tabular}{|c|c|c|c|c|c|c|}
\hline Variable & Predicted sign & & coef & ient & Chi-Square & p-value \\
\hline Intercept & & $\beta_{0}$ & $=$ & $-5.182^{* * * *}$ & 53.58 & 0.000 \\
\hline$N O$ & - & $\beta_{1}$ & $=$ & $-0.001^{* * * *}$ & 9.60 & 0.001 \\
\hline$L A$ & - & $\beta_{2}$ & $=$ & $0.218^{* * *}$ & 23.12 & 0.000 \\
\hline$S G$ & + & $\beta_{3}$ & $=$ & -0.003 & 0.13 & 0.721 \\
\hline DTR & + & $\beta_{4}$ & $=$ & 0.004 & 0.11 & 0.745 \\
\hline$R O A$ & + & $\beta_{5}$ & $=$ & $0.052^{* * *}$ & 104.55 & 0.000 \\
\hline$H T$ & + & $\beta_{6}$ & $=$ & $1.445^{* * *}$ & 250.86 & 0.000 \\
\hline Log likelihood & & -668.89 & & & & \\
\hline LR statistic & & 539.78 & & & & \\
\hline $\mathrm{N}$ & & 3845 & & & & \\
\hline
\end{tabular}

$* * *, * *, *$ indicate coefficient is significant at the $1 \%, 5 \%, 10 \%$ level, respectively.

Definitions of variables:

$Y$ : equal to 1 for firm with employee stock bonus, and 0 otherwise;

$N O$ : the number of employees;

$L A$ : the natural $\log$ of total asset;

$S G$ : the rate of sales growth;

$D T R$ : the ratio of $\mathrm{R} \& \mathrm{D}$ expenditure to sales;

$R O A$ : the rate of return on assets, which is defined as net income before interest and taxes divide by total assets;

$H T$ : industry type dummy, the electronics industry equals 1 , and 0 otherwise.

After the selection equation for employee stock bonus is established by the first stage of Heckman's 2-stage model, it can be used to estimate the probability of a firm adopting employee stock bonus and calculate the inverse Mill's ratio ( $L A M)$. The inverse Mill's ratio represents the self-selection correction term to solve the "self-selection bias" in regression models. In the second stage, the inverse Mill's ratio is included in our regression models to determine whether or not employee stock bonus reduces the share price of a firm.

$\underline{\text { Tests of } H_{1}}$

This study examines the relationship between a firm's equity market value and employee stock bonus it granted. Our empirical results are shown in Table 5. 
Table 5

Regression Analysis of the Impact of Employee Stock Bonus on equity market value

\begin{tabular}{|c|c|c|c|c|c|c|c|}
\hline \multirow{2}{*}{$\begin{array}{l}\text { Variable } \\
\text { Intercept }\end{array}$} & \multirow[t]{2}{*}{ Predicted sign } & \multicolumn{3}{|c|}{ Coefficient } & \multirow{2}{*}{$\begin{array}{c}\text { t-value } \\
-1.71\end{array}$} & \multirow{2}{*}{$\begin{array}{l}\text { p-value } \\
0.000\end{array}$} & \multirow{2}{*}{$\begin{array}{c}\text { VIF } \\
0\end{array}$} \\
\hline & & $\alpha$ & $=$ & $-0.248^{*}$ & & & \\
\hline$B V$ & + & $\beta_{0}$ & $=$ & $0.890^{* * *}$ & 2.55 & 0.011 & 7.955 \\
\hline$N I$ & + & $\beta_{1}$ & $=$ & $3.626^{* *}$ & 3.36 & 0.001 & 1.778 \\
\hline$S B O$ & - & $\beta_{2}$ & $=$ & $-3.345^{* * *}$ & -3.59 & 0.001 & 5.245 \\
\hline$G W$ & + & $\beta_{3}$ & $=$ & $0.517^{*}$ & 1.46 & 0.079 & 8.561 \\
\hline$L A M$ & & $\gamma$ & $=$ & $-0.031^{* * * *}$ & -1.20 & 0.231 & 1.013 \\
\hline Adjusted $R^{2}$ & & & & 0.649 & & & \\
\hline $\mathrm{N}$ & & & & 772 & & & \\
\hline
\end{tabular}

$* * *, * *, *$ indicate coefficient is significant at the $1 \%, 5 \%, 10 \%$ level, respectively.

See table 2 for definition of variables.

It reveals that the model's adjusted $R^{2}$ is 0.649 . As expected, the regression coefficients of book value $(B V)$ and net income $(N I)$ are significantly positive. These statistics suggest that there exists a negative effect of fair value of employee stock bonus $(S B O)$ on a firm's share price. These results are consistent with our $\mathrm{H}_{1}$. The higher the fair value of employee stock bonus is, the lower a firm's share price will be. Accounting information is important to help investors making predictions about the firm's future earnings and it will affect stock prices accordingly. Employee stock bonus is distributed from current profit or retained earnings in Taiwan. Under current accounting treatment in Taiwan, employee stock bonus is recorded and taxed at the par value of NT $\$ 10$ and regarded as a distribution of after-tax profits instead of a compensation cost. The positive side of this treatment is to attract and retain talented people by employee stock bonus. An employee will work harder to maximize his personal interest since he has a stake in the firm's shares. The negative side of employee stock bonus is its dilution of the existing shareholders' equity rights. Unless an employee works hard enough to increase a firm's value exceeding the dilution effect of employee stock bonus, the wealth of existing shareholders will shrink. However, no matter how employee stock bonus is presented in the financial statements, stock price will reflect all information in an efficient market any way, including the fair value information of employee stock bonus. Our empirical evidence shows that firms with employee stock bonus significantly weaken the firm's share price. The regression coefficient of growth opportunities $(G W)$ is significantly positive, suggesting that the ability of residual income valuation model to explain a stock price is higher when a firm's growth opportunities are better. That is, companies with higher growth opportunities will have larger equity market value, which is consistent with our expectation.

\section{CONCLUSIONS}

Our study examines the impact of employee stock bonus on the equity market value for firms listed on the Taiwan Stock Exchange. Truly, employee stock bonus plan has a motivational effect for employees. Due to un-recognizing treatment on the fair value of employee stock bonus as compensation expense in Taiwan, accounting earnings thus includes noise and impairs the relationship between earnings and stock price. Our empirical evidence indicates a significantly negative effect of fair value of employee stock bonus on share price for firms in Taiwan. There exists a significantly positive relationship between growth opportunities and share price. These statistics imply that the explanatory ability of earnings for stock prices increases when the firm's growth opportunities are higher.

The empirical results show that the fair value of employee stock bonus reduces a firm's equity market price. This conclusion can help designing an incentive mechanism to attract and retain talented employees and, at the same time, protect shareholders' equity rights. 


\section{AUTHOR INFORMATION}

Nien-Su Shih is a Ph.D. candidate at the Department of Accountancy, National Cheng Kung University. She is Lecturer at the Department of Accountancy, Feng Chia University. Her research areas are financial accounting and corporate governance.

\section{REFERENCES}

1. Chang, S. W. 1999. The Market Effect on the Information of Employee Stock Bonus: Evidence from Taiwanese Listed Electronics Firms. Master dissertation, Soochow University, Taipei, Taiwan.

2. Chen, A., and Wang, S. 2002. The Source of Competitive Strength for Knowledge Economics: The Global Unique Taiwan-style Employees Profit Sharing \& Stock Ownership System. Industry Forum 3(2): 1-19.

3. Coller M., and Higgs J. L. 1997. Firm Valuation and Accounting for Employee Stock Options. Financial Analysts Journal (February): 26-34.

4. Collins, D., and Kothari, S. 1989. An Analysis of Intertemporal and Cross-Sectional Determinants of Earnings Response Coefficients. Journal of Accounting and Economics 11(2-3): 143-181.

5. Core, J., and Guay, W. 1999. The Use of Equity Grants to Manage Optimal Equity Incentive Levels. Journal of Accounting and Economics 28(2): 151-184.

6. $\quad$ Espahbodi, H., Espahbodi, P., Rezaee Z., and Tehranian, H. 2002. Stock Price Reaction and Value Relevance of Recognition versus Disclosure: The Case of Stock-based Compensation. Journal of Accounting and Economics 33(3): 343-373.

7. Fama, E. F., and French, K. R. 1993. Common Risk Factors in the Returns on Stocks and Bonds. Journal of Financial Economics 33: 3-56.

8. Feltham, G. A., and Ohlson, J. A. 1995. Valuation and Clean Surplus Accounting for Operating and Financial Activities. Contemporary Accounting Research 11(2): 689-731.

9. Guay, W. 1999. The Sensitivity of CEO Wealth to Equity Risk: An Analysis of the Magnitude and Determinants. Journal of Financial Economics 53(1): 43-71.

10. Heckman, J. J. 1976. The Common Structure of Statistical Models of Truncation Sample Selection and Limited Dependent Variables and a Simple Estimator for Such Models. Annals of Economic and Social Measurement 5: 475-492.

11. Ittner, C. D., Lambert, R. A., Larcker, D. F. 2003. The Structure and Performance Consequences of Equity Grants to Employees of New Economy Firms. Journal of Accounting and Economics 34: 89-127.

12. Kole, S. 1991. An Investigation of the Bundling of Compensation Plans. Working Paper. University of Rochester, Rochester, NY.

13. MacKie-Mason, J. K. 1990. Do Taxes Affect Corporate Financing Decisions? Journal of Finance 45: 1471-1493.

14. Nalbantian, H. R.and Schotter, A. 1997. Productivity under Group Incentives: A experimental study. The American Economic Review 87(3): 314-341.

15. Ohlson, J. 1995. Earnings, Book Values, and Dividends in Security Valuation. Contemporary Accounting Research 11(2): 662-688.

16. Smith, C. W., and Watts, R. L. 1992. The Investment Opportunity set and Corporate Financing, Dividend Compensation Policies. Journal of Financial Economics 32 (3): 263-292.

17. Yoon, P. S., and Starks, L. T. 1995. Signaling, Investment Opportunities, and Dividends Announcements. Review of Financial Studies 8: 995-1018. 
NOTES 